\title{
Household Characteristics That Influence Simple Household Demand On Electricity
}

\author{
Tongam Sihol Nababan \\ Faculty of Economics, University of HKBP Nommensen, Medan \\ Jln. Sutomo No.4A Medan Sumatera Utara Indonesia Telp: + 62-061-4522922, \\ E-mail: ts_nababan@yahoo.com
}

Received: March 2015; Accepted: May 2015

\section{Abstract}

This research aims to analyze the characteristics of households that affect the electric energy consumption of simple households. The second objective is to analyze the probability of each of the factors affecting the electricity energy consumption of small household. The research was conducted in Medan City in the period of March 2014 to November 2014 with samples of 143 small households, the customer of PT. PLN (Persero) Medan, which use the power of electricity for TR-1 /450VA. Data were analyzed by using the logistic regression model. The estimation results indicated that (1) the higher the willingnes to pay (WTP) of households, the higher the tendency to consume electrical energy per month. (2) the closer the households residence to the city center, the higher the tendency to consume electrical energy than of the households residence in the suburbs, (3) increasingly unfavourable response to electrical quality, the higher the opportunity to consume a greater electric power monthly.

Keywords: simple household, electric energy, willingness to pay, electricity rates JEL Classification: D12, L94, Q41

\section{Karakteristik Rumah Tangga yang Mempengaruhi Permintaan Energi Listrik Rumah Tangga Sederhana}

\begin{abstract}
Abstrak
Penelitian ini bertujuan menganalisis karakteristik rumah tangga yang mempengaruhi konsumsi energi listrik rumah tangga sederhana. Tujuan kedua adalah menganalisis probabilitas dari masing-masing faktor yang berpengaruh terhadap konsumsi energi listrik rumah tangga sederhana. Penelitian dilaksanakan di Kota Medan pada periode Maret 2014 - Nopember 2014 dengan jumlah sampel 143 rumah tangga sederhana pelanggan PT. PLN (Persero) Kota Medan yaitu pengguna listrik PT. PLN (Persero) untuk TR-1/450VA. Data dianalisis dengan menggunakan model Regresi Logistik. Hasil estimasi menunjukkan bahwa: pertama, semakin tinggi kemampuan bayar (WTP) keluarga, maka kecenderungan keluarga tersebut mengkonsumsi energi listrik semakin besar, kedua, semakin ke tengah kota tempat tinggal keluarga maka kecenderungan keluarga tersebut mengkonsumsi energi listrik semakin besar daripada keluarga yang tinggal di pinggir kota, ketiga, semakin kurang baik tanggapan terhadap kualitas listrik maka semakin tinggi peluang untuk mengkonsumsi energi listrik lebih besar perbulannya.
\end{abstract}

Kata kunci: rumah tangga sederhana, energi listrik, willingness to pay, tarif listrik Klasifikasi JEL: D12, L94, Q41

\section{Pendahuluan}

Pembangunan ketenagalistrikan di Indonesia dihadapkan pada berbagai tantangan dan permasalahan, yaitu: keterbatasan kapasitas pembangkit, keterbatasan kemampuan pendanaan, kurangnya kemandirian industri ketenagalistrikan, tingginya ketergantungan terhadap bahan bakar minyak, rendahnya kinerja sarana dan prasarana dan belum tercapainya tingkat 


\section{Jurnal Ekonomi Pembangunan, 16 (1), Juni 2015, 61-74}

tarif yang ekonomis.

Perekonomian Indonesia yang sudah mulai membaik ditandai dengan pertumbuhan ekonomi rata-rata 4,2 persen per tahun selama 5 tahun terakhir (2010-2015) menyebabkan pertumbuhan penjualan energi listrik PLN ratarata 7 persen per tahun. Realisasi jumlah pelanggan listrik PLN selama periode 20052013 juga mengalami peningkatan rata-rata 5,52 persen per tahun. Jumlah pelanggan listrik PLN sebagian besar (93 persen) adalah pelanggan rumah tangga. Rasio elektrifikasi (perbandingan jumlah rumah tangga yang sudah berlistrik dengan jumlah rumah tangga yang ada) juga mengalami kenaikan dari 63,75 persen tahun 2009 menjadi 78,06 persen pada tahun 2013 (Statistik PLN, 2013).

Menurut Kuswara (1997), peningkatan permintaan kebutuhan listrik secara umum dapat disebabkan oleh tiga faktor yaitu 1) peningkatan kegiatan ekonomi yang sejalan dengan pertumbuhan GDP (Gross Domestic Product), 2) peningkatan tingkat coverage atau tingkat elektrifikasi, dan 3) pergantian pembangkit captive (pembangkit sendiri) yang biasanya kurang efisien karena skala ekonomisnya rendah dan tumbuhnya pembangkit captive karena kurangnya distribusi dan transmisi PT PLN. Selain ketiga faktor utama di atas, pertumbuhan penduduk juga menjadi salah satu faktor utama yang harus dipertimbangkan (RUPTL 2006-2015). Tingginya permintaan listrik dapat juga dipengaruhi oleh kegiatan ekonomi, khususnya di daerah perkotaan (urban areas), dan peningkatan kegiatan ekonomi perkotaan ini akan menarik masyarakat pedesaan (rural people) untuk bermigrasi ke kota, sehingga kebutuhan listrik pun akan meningkat (Resosudarmo dan Tanujaya, 2002). Selain beberapa faktor yang mempengaruhi permintaan energi listrik sebagaimana disebutkan di atas, salah satu faktor yang paling penting pengaruhnya adalah faktor harga atau tarif listrik. Dalam penetapan tarif listrik pemerintah berusaha agar masyarakat mencapai kesejahteraan yang maksimum, yaitu pada suatu tingkat produksi yang biaya marginalnya sama dengan kemampuan dan kemauan masyarakat membayar harga (ability and willingness to pay).

Di masa yang akan datang, pertumbuhan ekonomi, jumlah penduduk, jumlah pelanggan listrik PLN, dan rasio elektrifikasi diproyeksikan tetap meningkat. Hasil pertumbuhan ekonomi akan meningkatkan pendapatan masyarakat dan mendorong meningkatnya permintaan akan barang-barang/peralatan listrik seperti radio, televisi, alat pendingin, lemari es, serta alat-alat listrik rumah tangga lainnya.

Bartel \& Fiebeg (2000), Rab (2001), Meetamehra (2002), Larsen \& Nesbakken (2002), Sweeney (2004) mengemukakan bahwa pemanfaatan energi listrik untuk menghasilkan jasajasa energi dalam rumah tangga haruslah dilihat sebagai hubungan antara ketersediaan atau stok peralatan (capital stock, or stock of appliances, or stock of equipment) dan intensitas penggunaan peralatan (utilization rate) tersebut. Sedangkan Guertin et al. (2003) dan Halvorsen et al. (2003) berpendapat bahwa dalam penggunaan energi listrik juga harus mempertimbangkan karakteristik demografik rumah tangga yang dapat mempengaruhi utilitas energi listrik tersebut.

Fenomena-fenomena atau isu yang menunjukkan berbagai karakteristik penggunaan energi listrik dalam rumah tangga menjadi sangat penting dan menarik untuk dikaji. Penelitian ini bertujuan untuk mendeskripsikan dan menganalisis tentang karakteristikkarakteristik penggunaan energi listrik yang diyakini dapat mempengaruhi permintaan energi listrik rumah tangga. Secara umum, karakteristik ini meliputi lamanya menjadi pelanggan, jumlah ruangan, jumlah alat listrik yang dimiliki, jumlah energi listrik yang digunakan, dan sumber energi lain sebagai pengganti listrik dan karakteristik lainnya. Dalam penelitian karakteristik rumah tangga difokuskan pada variabel konsumsi energi listrik, pendapatan, WTP (willingness to pay), penggunaan alat-alat listrik, lokasi tempat tinggal rumah tangga, serta tanggapan terhadap kecukupan daya listrik, kualitas listrik, dan tarif listrik.

Konsumen energi listrik kelompok rumah tangga yang berlangganan pada PT PLN (Persero) Cabang Kota Medan yang didasarkan 


\section{Jurnal Ekonomi Pembangunan, 16 (1), Juni 2015, 61-74}

pada penggolongan tarif dan batas daya yang terdiri atas R-1/TR $450 \mathrm{VA}, \mathrm{R}-1 / \mathrm{TR} 900 \mathrm{VA}, \mathrm{R}$ 1/TR 1300 VA, R-1/TR 2200 VA, R-2/TR 2201 s.d. 6600 VA, dan R-3/TR > 6600 VA. Dalam penelitian ini yang menjadi responden adalah kelompok rumah tangga sederhana dengan golongan tarif dan batas daya yang R-1/TR 450 VA.

Penelitian ini bertujuan untuk: (1) menganalisis karakteristik rumah tangga yang dapat mempengaruhi konsumsi energi listrik rumah tangga sederhana (pengguna listrik TR-1/450 VA), (2) menganalisis probabilitas dari masingmasing faktor yang berpengaruh terhadap konsumsi energi listrik rumah tangga sederhana dengan menggunakan regresi logistik.

Model Permintaan/Konsumsi Energi Listrik Rumah Tangga. Secara umum, konsumsi energi listrik tergantung pada stok atau keberadaan/ketersediaan peralatan-peralatan listrik dan intensitas penggunaan peralatanperalatan listrik tersebut dalam rumah tangga (Wilder \& Willenborg, 1975; Garbacz, 1984). Oleh karena itu, dalam membuat estimasi fungsi permintaan energi listrik rumah tangga harus memasukkan unsur stok kapital atau stok peralatan-peralatan listrik dan tingkat penggunaannya, dengan asumsi bahwa dalam jangka pendek stok kapital dianggap tidak berubah atau tetap (Wilder \& Willenborg, 1975; Amarullah, 1984; Silk \& Joutz, 1997; Reiss \& White, 2001). Namun, estimasi fungsi permintaan energi listrik rumah tangga tidak hanya memasukkan variabel-variabel yang menyangkut energi listrik itu sendiri seperti harga listrik, jumlah energi listrik, stok kapital alatalat listrik, tetapi juga mempertimbangkan variabel-variabel lain yang dapat mempengaruhi fungsi utilitas permintaaan energi listrik seperti unsur-unsur demografi dan sosial tempat rumah tangga berada. Dengan demikian, permintaan atau konsumsi energi listrik rumah tangga dipengaruhi oleh pendapatan rumah tangga, harga atau tarif energi listrik, stok alat-alat listrik (appliances), karakteristik rumah tangga (household characteristics), karakteristik rumah (housing characteristics), dan variabel-variabel lain yang relevan.

Salah satu faktor yang paling penting dalam permintaan energi listrik rumah tangga adalah harga/tarif listrik. Namun dalam studi empirik, penggunaan proksi harga/tarif ini berbeda-beda, apakah menggunakan harga rata-rata atau harga marginal. Pilihan antara menggunakan harga rata-rata ataupun harga marginal merupakan isu metodologi yang penting dalam analisis permintaan energi listrik. Dalam penelitiannya, Wilder \& Willenborg (1975) menggunakan harga ratarata (average price) yang didasarkan pada rekening listrik bulanan, dengan alasan bahwa konsumen kurang mengerti tentang harga marginal. Alasan lain, sebagaimana dibuktikan oleh Halvorsen (1975), McKean dan Winger (1992) bahwa dalam bentuk log-linear baik untuk fungsi permintaan, maupun fungsi harga; nilai elastisitas permintaan dengan menggunakan harga rata-rata tidak jauh berbeda dengan nilai elastisitas permintaan apabila menggunakan harga marginal.

Sehubungan dengan harga/tarif listrik, sampai saat ini di Indonesia harga listrik masih ditetapkan berdasarkan sudut pandang produsen saja, dalam hal ini PT PLN dan pemerintah. Penetapan harga belum sesuai dengan harga pasar karena harga listrik selalu ditetapkan oleh pemerintah (regulated) dengan alasan bahwa listrik adalah barang publik yang harus disubsidi untuk tujuan-tujuan keadilan dan sosial. Oleh karena itu, dalam penelitian ini harga/tarif listrik akan diproksi dengan variabel WTP (willingness to pay) dengan menggunakan metode CV (contingent valuation). Proksi harga/tarif dengan WTP melalui metode CV diartikan sebagai upaya untuk memperoleh langsung berapa kemauan/ kesediaan konsumen untuk membayar terhadap harga/tarif listrik yang digunakan. Adapun format metode CV yang akan digunakan untuk memperoleh nilai WTP adalah closed-ended referendum format (pertanyaan tertutup).

Penggunaan variabel WTP sebagai proksi terhadap harga/tarif listrik dapat dimungkinkan dengan alasan 1) WTP konsumen dapat mengungkapkan nilai atau harga yang sebenarnya dari suatu barang atau jasa (Nam \& Son, 2005), 2) sistem penetapan harga/tarif listrik di Indonesia berbentuk increasing block-rate 


\section{Jurnal Ekonomi Pembangunan, 16 (1), Juni 2015, 61-74}

pricing sehingga harga berbeda untuk setiap tingkat penggunaan dan strata golongan tarif (daya). Variabel harga yang sesuai dengan bentuk ini adalah harga marginal ataupun harga rata-rata, tetapi jika datanya adalah data runtut waktu (time series) (Amarullah, 1984). Sedangkan dalam penelitian ini data yang digunakan adalah data cross section dari konsumen rumah tangga.

Estimasi model atau fungsi permintaan energi listrik rumah tangga dapat dispesifikasikan dalam bentuk persamaan tunggal dan persamaan simultan. Beberapa studi seperti yang dilakukan oleh Amarullah (1983), Wilder (1992), Jung (1993) menggunakan model permintaan energi listrik rumah tangga dalam bentuk persamaan tunggal dengan menggunakan Ordinary Least Square (OLS). Estimasi model atau fungsi permintaan energi listrik rumah tangga yang dispesifikasikan dalam bentuk persamaan simultan telah dilakukan antara lain oleh Wilder \& Willenborg (1975), Maddigan et al (1983), dan Garbacz (1984).

Namun dalam penelitian ini, untuk mengestimasi karakteristik-karakteristik rumah tangga yang mempengaruhi konsumsi energi listrik rumah tangga digunakan Model Regresi Logistik. Model Regresi Logistik merupakan suatu metode analisis data yang digunakan untuk mencari hubungan antara variabel respon $(y)$ yang bersifat biner atau dikotomus dengan variabel prediktor $(x)$ yang bersifat polikotomus (Hosmer dan Lemeshow, 2000).

Spesifikasi Model Regresi Logistik. Model Regresi Logistik digunakan untuk memodelkan hubungan antara variabel respon (Y) yang berskala biner dengan variabel independen kategori dan atau kontinu. Model ini adalah bentuk umum dari model logit untuk respon biner. Untuk variabel Y dengan kategori nominal memiliki sebaran Bernouli dengan fungsi sebaran peluang:

$P\left(Y=y_{i}\right)=\pi i^{y i}\left(1-\pi_{i}\right)^{1-\mathrm{yi}}$

dengan $\pi_{j}=$ peluang suatu kejadian ke-i yang bernilai $Y=1$, di mana nilai yi antara 0 dan 1 .
Model dari regresi logistik adalah:

$$
\pi_{\mathrm{i}}(\mathrm{x})=\frac{\exp \left\{\beta_{0}+\beta_{\mathrm{i}} \mathrm{x}_{\mathrm{ij}}+\ldots+\beta_{\mathrm{p}} \mathrm{x}_{\mathrm{pj}}\right\}}{1+\exp \left\{\left\{\beta_{0}+\beta_{\mathrm{i}} \mathrm{x}_{\mathrm{ij}}+\ldots+\beta_{\mathrm{p}} \mathrm{x}_{\mathrm{pj}}\right\}\right.}
$$

Model tersebut kemudian ditransformasi logit menjadi:

$\mathrm{g}(\mathrm{x})=\ln \left[\frac{\pi_{j}}{1-\pi j}\right]$

dengan penduga linier: $\mathrm{g}(\mathrm{x})=\beta_{0}+\beta_{i} x_{i j}+\ldots+$ $\beta_{p} x_{p j}$, dengan $\mathrm{p}=$ jumlah peubah penjelas dan $\mathrm{j}$ $=1, \ldots, n$.

Untuk memeriksa peranan variabel independen dalam model, dilakukan pengujian terhadap parameter model. Uji yang digunakan dalam penelitian ini adalah Statistik Uji-G dan Statistis Uji-Wald (W).

Statistik Uji-G adalah uji rasio kemungkinan (likelihood ratio test) yang digunakan untuk menguji peranan variabel independen di dalam model secara bersama-sama (Hosmer dan Lemeshow, 2000). Rumus umum uji-G untuk menguji hipotesis:

$\mathrm{H}_{0}: \beta_{1}=\beta_{2}=\ldots=\beta_{\mathrm{P}}=0$

$\mathrm{H}_{1}$ : minimal ada satu $\beta_{1} \neq 0$,

dengan $i=1,2, \ldots$, adalah:

$\mathrm{G}=2 \ln \left[\frac{\text { likelihood tanpa variabel independen }}{\text { likelihood dengan variabel independen }}\right]$

di mana statistik uji ini mengikuti sebaran $x^{2}$ dengan derajat bebas $p$.

Statistik Uji Wald digunakan untuk menguji parameter $\beta i$ secara parsial. Rumus umum dari uji-Wald untuk menguji hipotesis:

$\mathrm{H}_{0}: \beta_{\mathrm{i}}=0$

$\mathrm{H}_{1}: \beta_{\mathrm{i}} \neq 0$ dengan $\mathrm{I}=1,2, \ldots \mathrm{p}$, adalah:

$\mathrm{W}_{\mathrm{i}}=\frac{\widehat{\beta} \mathrm{i}}{\mathrm{S} \hat{E}(\widehat{\beta} \mathrm{i})}$ 


\section{Jurnal Ekonomi Pembangunan, 16 (1), Juni 2015, 61-74}

di mana $\hat{\beta}_{\text {i }}$ adalah penduga $\beta_{\text {i }}$ dan $\mathrm{S} \hat{E}\left(\hat{\beta}_{\mathrm{i}}\right)$ merupakan penduga galat baku dari $\beta_{\text {i }}$. Statistik ujiWald mengikuti sebaran normal baku jika hipotesis $\beta_{\mathrm{i}}=0$.

Setelah diperoleh model terbaik berdasarkan kriteria uji-uji tersebut, dilakukan interpretasi koefisien untuk melihat pengaruh nyata dari variabel-variabel independen yang terpilih. Interpretasi koefisien untuk model ini dapat dilakukan dengan melihat nilai ratio odds-nya. Rasio odds adalah ukuran asosiasi yang memperkirakan berapa besar kecenderungan pengaruh peubah-peubah penjelas terhadap peubah respon. Rasio odds untuk $\mathrm{Y}=\mathrm{j}$ terhadap $\mathrm{Y}=\mathrm{k}$ yang dihitung pada dua nilai (misal $\mathrm{x}=\mathrm{a}$ dan $\mathrm{x}$ $=\mathrm{b}$ ) adalah:

$$
\begin{aligned}
\Psi(\mathrm{a}, \mathrm{b}) & =\frac{P\langle Y=j \mid x=a\rangle / P\langle Y=k \mid x=a\rangle}{P\langle Y=j \mid x=b\rangle / P\langle Y=k \mid x=b\rangle} \\
& =\exp \left\{\beta_{\mathrm{i}}(\mathrm{a}-\mathrm{b})\right\}
\end{aligned}
$$

sehingga jika $a-b=1$ maka $\Psi=\exp \left(\beta_{\mathrm{i}}\right)$ dan memiliki ukuran $\Psi$ yang selalu positif.

Dalam interpretasi koefisien dari rasio odds untuk peubah penjelas yang berskala nominal, $\mathrm{X}=0$ memiliki kecenderungan untuk $\mathrm{Y}=0$ sebesar $\Psi$ kali dibandingkan dengan peubah $\mathrm{X}=1$. Sedangkan untuk peubah penjelas yang kontinu, jika $\Psi$ lebih besar atau sama dengan satu, maka semakin besarnya nilai peubah $\mathrm{X}$ diikuti dengan semakin besarnya kecenderungan untuk $\mathrm{Y}=0$ (Hosmer dan Lemeshow, 2000).

\section{Metode Penelitian}

\subsection{Lokasi Penelitian}

Lokasi penelitian berada di Kota Medan yang termasuk dalam daerah operasional PT PLN (Persero) Wilayah Operasional II Provinsi Sumatera Utara, yaitu PT. PLN (Persero) Cabang Medan yang terdiri atas 4 rayon dan 4 ranting yang tersebar di seluruh Kota Medan dan sekitarnya. Daerah rayon terdiri atas
Rayon Medan Kota, Rayon Medan Baru, Rayon Medan Selatan, dan Rayon Medan Timur. Sedangkan ranting terdiri atas Ranting Belawan, Ranting Helvetia, Ranting Sunggal, dan Ranting Labuhan.

Dalam penelitian ini tidak seluruh rayon ataupun ranting yang disurvei, tetapi hanya dua rayon dan dua ranting saja yang dipilih untuk mewakili masing-masing rayon (tengah kota) ataupun ranting (pinggir kota). Pemilihan dua rayon dan dua ranting didasarkan pada homogenitas dalam pola penggunaan (konsumsi) listrik untuk setiap golongan/strata, yang meliputi jenis dan jumlah alat-alat listrik yang digunakan, waktu penggunaan listrik dan pola hidup. Setelah dilakukan survei, untuk mewakili rayon (tengah kota), dipilih Rayon Medan Kota dan Rayon Medan Timur. Untuk mewakili ranting (pinggir kota) dipilih Ranting Helvetia dan Ranting Sunggal. Pemilihan kedua rayon dan ranting didasarkan pada homogenitas dalam pola penggunaan energi listrik.

\subsection{Sampel dan Data}

Populasi penelitian ini adalah konsumen energi listrik kelompok rumah tangga sederhana yang berlangganan pada PT PLN (Persero) Cabang Kota Medan yaitu golongan tarif dan batas daya R-1/TR 450 VA. Penentuan sampel dalam penelitian ini menggunakan metode Multistage Sampling with purposive, yaitu purposive-nya adalah sampel rumah tangga yang hanya menggunakan energi listrik untuk keperluan konsumsi rumah tangga saja, di mana energi listrik sebagai produk akhir. Dalam pengambilan sampel clusternya adalah daerah tengah kota daerah pinggir kota.

Jumlah sampel yang digunakan dalam penelitian ini sebanyak 170 sampel rumah tangga. Penarikan sampel rumah tangga dilakukan secara random dengan sistematis. Namun setelah semua data dikumpulkan, kemudian dilakukan pengeditan, ternyata tidak semua data (kuesioner) yang terkumpul bisa digunakan dalam penelitian ini. Ada beberapa data rumah tangga untuk data tertentu kosong dan tidak konsisten dengan karakteristiknya. Setelah data diseleksi, jumlah responden atau 


\section{Jurnal Ekonomi Pembangunan, 16 (1), Juni 2015, 61-74}

sampel yang digunakan sebanyak 143 sampel rumah tangga.

Data yang digunakan dalam penelitian ini adalah data primer meliputi: 1) jumlah permintaan atau konsumsi energi listrik rata-rata rumah tangga selama tiga bulan terakhir; 2) rekening energi listrik selama tiga bulan terakhir; 3) stok-kapital alat-alat listrik dalam rumah tangga ; 4) pendapatan rumah tangga; 5) WTP konsumen rumah tangga terhadap energi listrik; 6) karakteristik-karakteristik rumah tangga, seperti: jumlah anggota keluarga, usia anggota keluarga, tingkat pendidikan, pekerjaan kepala keluarga, kegiatan keluarga, etnis, lokasi, dan persepsi terhadap pelayanan listrik secara umum oleh PT PLN (Persero); 7) karakteristik-karakteristik bangunan rumah, seperti jumlah ruangan/kamar, ukuran/luas bangunan.
Pengumpulan data dilakukan selama periode bulan Januari 2014 sampai dengan periode bulan September 2014.

\subsection{Definisi Operasional}

Variabel respon $(\mathrm{Y})$ terdiri dari konsumsi energi listrik tumah tangga, sedangkan variabel prediktor terdiri dari pendapatan, WTP (willingness to pay), indeks penggunaan alat-alat listrik, lokasi tempat tinggal rumah tangga, serta tanggapan terhadap kecukupan daya listrik, kualitas listrik dan tarif listrik. Untuk memudahkan pengenalan terhadap variabelvariabel dalam model, baik variabel respon maupun variabel prediktor, perlu diuraikan defenisi operasional serta pengukuran dari setiap variabel seperti disajikan pada Tabel 1.

Tabel 1. Definisi Operasional Variabel Penelitian

\begin{tabular}{|c|c|c|c|}
\hline Variabel & Definisi & Kategori & Kode \\
\hline $\begin{array}{l}\text { Konsumsi Energi } \\
\text { Listrik Rumah } \\
\text { Tangga (Variabel } \\
\text { respon : Y) }\end{array}$ & $\begin{array}{l}\text { Jumlah energi listrik yang dikonsumsi oleh } \\
\text { konsumen rumah tangga yang diperoleh } \\
\text { langsung dari rekening listrik bulanan selama } \\
3 \text { bulan terakhir yang diukur dalam kilowatt- } \\
\text { hours (KWh). }\end{array}$ & $\begin{array}{l}\text { - Di bawah } 100 \mathrm{KWh} \\
\text { - Di atas } 100 \mathrm{KWh}\end{array}$ & $\begin{array}{l}0 \\
1\end{array}$ \\
\hline $\begin{array}{l}\text { Pendapatan } \\
\text { (PEND1 dan PEND2) }\end{array}$ & $\begin{array}{l}\text { Total pendapatan yang diperoleh anggota } \\
\text { rumah tangga, baik dari kepala rumah tangga } \\
\text { maupun anggota rumah tangga yang } \\
\text { memanfaatkan listrik selama } 3 \text { bulan } \\
\text { terakhir, diukur dalam rupiah per bulan } \\
\text { (Rp/bulan). }\end{array}$ & $\begin{array}{l}\text { Pendapatan } 1 \\
\text { (PEND1) : } \\
\text { - Di bawah Rp } 2 \text { juta } \\
\text { - Lainnya } \\
\text { Pendapatan } 2 \\
\text { (PEND2) : } \\
\text { - Rp } 2 \text { juta - Rp } 4 \text { juta } \\
\text { - Lainnya }\end{array}$ & $\begin{array}{l}0 \\
1\end{array}$ \\
\hline $\begin{array}{l}\text { Willingness To Pay *) } \\
\text { (WTP) }\end{array}$ & $\begin{array}{l}\text { Kesediaan atau kemauan konsumen rumah } \\
\text { tangga untuk membayar harga energi listrik } \\
\text { yang digunakannya setiap bulan, diukur } \\
\text { dalam rupiah per bulan (Rp/bulan). }\end{array}$ & $\begin{array}{l}\text { - Di bawah Rp } 100 \text { ribu } \\
\text { - Di atas Rp } 100 \text { ribu }\end{array}$ & $\begin{array}{l}1 \\
0\end{array}$ \\
\hline $\begin{array}{l}\text { Indeks Alat Listrik }{ }^{* *} \text { ) } \\
\text { (INDAL) }\end{array}$ & $\begin{array}{l}\text { Indeks yang mengukur stok-kapital dan } \\
\text { penggunaan (utilization rate) peralatan listrik } \\
\text { yang dimiliki oleh setiap konsumen rumah } \\
\text { tangga. Untuk mengukur indeks ini } \\
\text { digunakan model Jung (1993). }\end{array}$ & $\begin{array}{l}\text { - Di bawah } 20 \\
\text { - Di atas } 20\end{array}$ & $\begin{array}{l}1 \\
0\end{array}$ \\
\hline $\begin{array}{l}\text { Lokasi Tempat } \\
\text { Tinggal } \\
\text { (LOKASI) }\end{array}$ & $\begin{array}{l}\text { Tempat yang menunjukkan posisi strategis di } \\
\text { rayon atau di ranting mana konsumen rumah } \\
\text { tangga berada atau bertempat tinggal. }\end{array}$ & $\begin{array}{l}\text { - Pinggir Kota } \\
\text { - Tengah Kota }\end{array}$ & $\begin{array}{l}1 \\
0\end{array}$ \\
\hline
\end{tabular}


Jurnal Ekonomi Pembangunan, 16 (1), Juni 2015, 61-74

\begin{tabular}{|c|c|c|c|}
\hline $\begin{array}{l}\text { Kecukupan Daya } \\
\text { Listrik (DAYA) }\end{array}$ & $\begin{array}{l}\text { Tanggapan atau respon rumah tangga } \\
\text { terhadap kecukupan daya listrik sebesar } 450 \\
\text { VA yang digunakan sebagai sumber energi. }\end{array}$ & $\begin{array}{l}\text { - Tidak Cukup } \\
\text { - Cukup }\end{array}$ & $\begin{array}{l}1 \\
0\end{array}$ \\
\hline $\begin{array}{l}\text { Kualitas Listrik } \\
\text { (KUAL) }\end{array}$ & $\begin{array}{l}\text { Tanggapan atau respon rumah tangga } \\
\text { terhadap kualitas listrik sebesar } 450 \text { VA yang } \\
\text { digunakan sebagai sumber energi. }\end{array}$ & $\begin{array}{l}\text { - Kurang Baik } \\
\text { - Baik }\end{array}$ & $\begin{array}{l}1 \\
0\end{array}$ \\
\hline $\begin{array}{l}\text { Tarif/harga Listrik } \\
\text { (TARIF) }\end{array}$ & $\begin{array}{l}\text { Tanggapan atau respon rumah tangga } \\
\text { terhadap tarif atau harga listrik yang berlaku } \\
\text { saat ini. }\end{array}$ & $\begin{array}{l}\text { - Tidak Terjangkau } \\
\text { (Mahal) } \\
\text { - Cukup Terjangkau }\end{array}$ & 1 \\
\hline
\end{tabular}

Catatan :

*) Data WTP untuk harga listrik ini diperoleh dengan menggunakan metode contingent economic valuation survey dalam bentuk closed ended referendum elicitation format (bidding game format), atau pertanyaan tertutup dalam kuesioner sebagaimana telah digunakan oleh Economy and Environtment Program for Southeast Asia (EEPSEA) (Nam \& Son, 2001, 2005).

**) Untuk mengukur indeks alat-alat listrik ini digunakan model Jung (1993) sebagai berikut:

$$
I N D A L=\frac{\left(\sum_{k=1}^{n} B_{k} O_{i, k}\right) 100}{\sum_{k=1}^{n} B_{k} C_{k}}
$$

INDAL adalah appliances index, Oi,k adalah jumlah peralatan listrik k yang dimiliki oleh rumah tangga i. Denominator (penyebut) INDAL diperoleh dengan mengalikan rata-rata daya dari masing- peralatan listrik (Bk dalam watt) dengan jumlah maksimum peralatan listrik dari masing-masing rumah tangga (Ck), sedangkan enumerator (pembilang) diperoleh dengan mengalikan rata-rata daya (Bk) dengan jumlah peralatan listrik $(\mathrm{Oi}, \mathrm{k})$.

\section{Hasil dan Pembahasan}

\subsection{Karakteristik Variabel-variabel yang Berhubungan dengan Konsumsi Energi Listrik Rumah Tangga Sederhana TR-1/ 450VA}

Karakteristik konsumsi energi listrik rumah tangga responden menggambarkan bagaimana variabel-variabel yang berhubungan langsung terhadap proses pemanfaatan energi listrik di rumah tangga sederhana. Secara umum, variabel-variabel ini meliputi: jumlah konsumsi listrik per bulan, pendapatan perbulan, willingness to pay (kemampuan membayar), lamanya menjadi pelanggan, jumlah ruangan, jumlah alat listrik yang dimiliki, jumlah energi listrik yang digunakan, dan sumber energi lain sebagai pengganti listrik, lokasi, tanggapan terhadap kecukupan daya listrik, dan kualitas listrik. Namun dalam penelitian ini variabelvariabel yang dieksplorasi hanyalah variabelvariabel utama saja yaitu: jumlah konsumsi listrik perbulan, jumlah pendapatan, jumlah willingness to pay, indeks alat-alat listrik, lokasi, tanggapan terhadap kecukupan daya listrik, kualitas listrik, dan tarif listrik.

Berdasarkan Tabel 2 dapat dilihat bahwa rata-rata jumlah energi listrik yang digunakan per bulan adalah 107,05 KWh. Jika dibandingkan dengan rata-rata penggunaan pelanggan Kota Medan, maka rata-rata penggunaan per bulan rumah tangga responden sudah di atas rata-rata penggunaan Kota Medan yang hanya $95 \mathrm{KWh}$ perbulan. Total pendapatan tertinggi responden rumah tangga sebesar Rp8 juta dan terendah Rp1 juta. Pada Gambar 1 dapat dilihat bahwa sebagian besar kepala rumah tangga responden bekerja sebagai wiraswasta, yang diindikasikan lebih banyak pendapatannya dibandingkan dengan jenis pekerjaan lain. Sedangkan WTP (willingness to pay) responden rumah tangga rata-rata $R$ p43.286,71 per bulan.

Pemilikan dan penggunaan jenis peralatan listrik ini disesuaikan dengan besarnya daya listrik yang dimiliki oleh rumah tangga. Untuk rumah tangga sederhana TR-1/450 VA umumnya menggunakan peralatan listrik yang biasa 
Avalaible online at http://journals.ums.ac.id

Jurnal Ekonomi Pembangunan, 16 (1), Juni 2015, 61-74

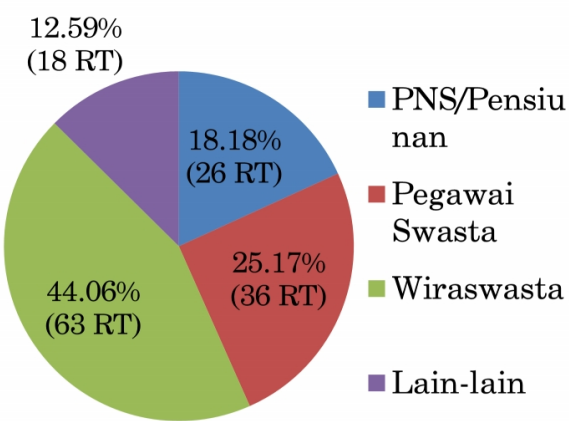

Gambar 1. Jenis Pekerjaan Responden Rumah Tangga $(\mathrm{n}=143)$

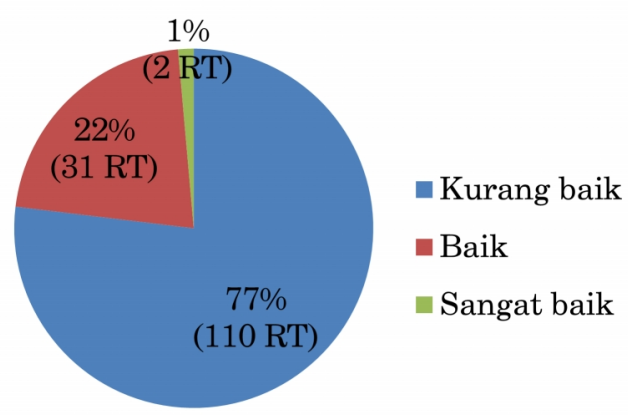

Gambar 3. Tanggapan Responden Terhadap Kualitas Listrik ( $\mathrm{n}=143$ )

dipakai untuk kebutuhan-kebutuhan pokok dan mempunyai daya (watt) yang rendah, seperti bola lampu, setrika, televisi, tape/radio, kipas angin, kulkas. Tabel 2 menunjukkan bahwa kepemilikan alat listrik rata-rata 14,32 unit per rumah tangga dengan rata-rata indeks alat listrik adalah sebesar 20,07. Deskripsi tanggapan terhadap kecukupan daya listrik, kualitas listrik, serta tarif listrik disajikan pada Gambar 2, Gambar 3, dan Gambar 4.

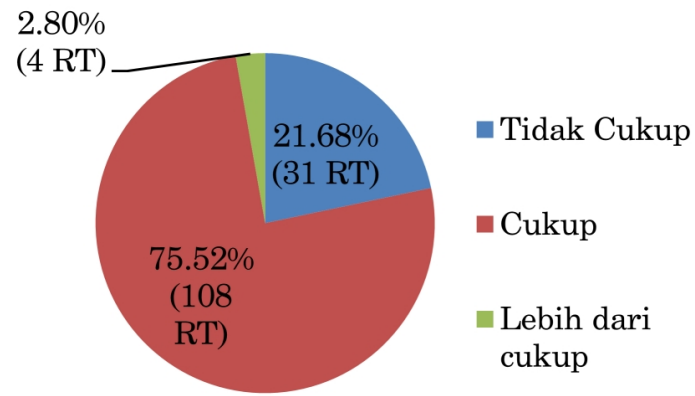

Gambar 2. Tanggapan Responden Terhadap Kecukupan Daya Listrik ( $\mathrm{n}=143)$

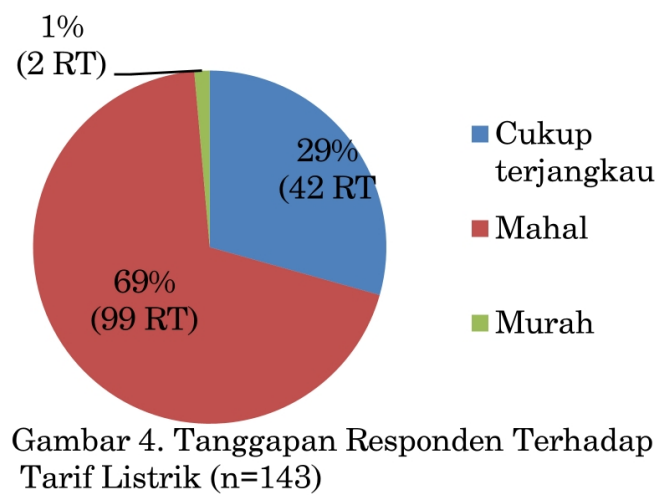

\subsection{Hasil Estimasi Regresi Logistik}

Dengan menggunakan perangkat lunak SPSS version 19.0 dapat ditentukan hubungan antara variabel dependen dengan variabel independen di dalam model serta kelayakan model, yang meliputi validasi model dan kalibrasi model.

\subsubsection{Validasi Model}

Analisis penentuan hubungan antara variabel dependen dan variabel independen di dalam model serta kelayakan model di dalam

Tabel 2. Data Deskriptif Variabel-variabel Yang Mempengaruhi Konsumsi Listrik Rumah Tangga Sederhana TR-1/450VA

\begin{tabular}{lrrr}
\hline \multicolumn{1}{c}{ Variabel } & Minimum & Maximum & Rata-rata \\
\hline Konsumsi Listrik (KWh/bulan) & 22,67 & 232,67 & 107,05 \\
Pendapatan (Rupiah/bulan) & 1.000 .000 & 8.000 .000 & $2.680 .594,41$ \\
WTP (Rupiah/bulan) & 10.000 & 200.000 & $43.286,71$ \\
Jumlah alat listrik (unit) & 6 & 36 & 14,32 \\
Indeks Alat Listrik & 5,93 & 50,09 & 20,07 \\
\hline
\end{tabular}

Sumber : Hasil Pengolahan Data, 2014. 


\section{Jurnal Ekonomi Pembangunan, 16 (1), Juni 2015, 61-74}

menyatakan hubungan antara variabel dependen dengan variabel independen, dapat dilihat pada Tabel 3 .

Pada Tabel 3 terlihat bahwa untuk model konsumsi energi listrik rumah tangga sederhana mempunyai peluang chi-square 46,507 dengan tingkat signifikansi 0,000 atau model konsumsi energi listrik rumah tangga sederhana mempunyai signifikansi pada tingkat $5 \%$. Ini menunjukkan bahwa model yang disusun mempunyai hubungan yang signifikan antara variabel dependen dengan variabel independennya.

Tabel 3. Omnibus Tests of Model Coefficient

\begin{tabular}{lllll}
\hline & & Chi-square & df & Sig. \\
\hline \multirow{2}{*}{ Step 1 } & Step & 46,507 & 8 &, 000 \\
& Block & 46,507 & 8 &, 000 \\
& Model & 46,507 & 8 &, 000 \\
\hline
\end{tabular}

Tabel 4 menunjukkan nilai Nagelkerke $\mathrm{R}^{2}$ sebesar 0,376 dapat diinterpretasikan seperti koefisien determinasi pada regresi linier berganda, yang berarti bahwa proporsi varians dari konsumsi energi listrik rumah tangga sederhana dapat dijelaskan oleh model sebesar $37,60 \%$.

Mengacu kepada Washington, et al. (2003), dijelaskan bahwa pada model pilihan dengan model logistik, semakin tinggi nilai pseudo $\mathrm{R}^{2}$ (goodness of fit), semakin baik model yang disusun. Akan tetapi hal ini tidak selalu tepat. O'Donnel dan Connor (2002) sebagaimana dikutip oleh Woro (2011) menyatakan bahwa secara praktis nilai tersebut dapat diabaikan karena untuk model regresi logistik ini tidak ada nilai baku pseudo $\mathrm{R}^{2}$ yang dapat dijadikan sebagai acuan kelayakan model. Nilai ini mempunyai batas atas baik secara teoritis dan empiris yang selalu kurang dari satu. Oleh karena itu digunakan cara lain untuk menentukan kelayakan model yaitu dengan uji Hosmer and Lemeshow (H-L test).
Tabel 4. Koefisien Determinasi Model

\begin{tabular}{cccc}
\hline Step & $\begin{array}{c}-2 \text { Log } \\
\text { likelihood }\end{array}$ & $\begin{array}{c}\text { Cox \& Snell } \\
\text { R Square }\end{array}$ & $\begin{array}{c}\text { Nagelkerke } \\
\text { R Square }\end{array}$ \\
\hline & & &, 376 \\
\hline
\end{tabular}

Uji kelayakan model atau model goodness of fit dilakukan dengan menggunakan prinsip Hosmer and Lameshow (H-L test). Jika nilai uji H-L sama atau kurang dari $5 \%$ berarti ada perbedaan yang signifikan antara model dengan nilai observasinya, dimana kelayakan model tidak baik karena model dianggap tidak bisa memprediksi nilai observasinya. Jika nilai statistik Hosmer and Lameshow's goodness of fit lebih besar dari $5 \%$ berarti model mampu untuk memprediksi nilai observasinya dengan kepercayaan $95 \%$.

Tabel 5. Uji Hosmer and Lemeshow Test

\begin{tabular}{cccc}
\hline Step & Chi-square & df & Sig. \\
\hline 1 & 3,234 & 8 &, 919 \\
\hline
\end{tabular}

Tabel 5 memperlihatkan nilai signifikansi berdasarkan uji Hosmer dan Lameshow (H-L) adalah 0.919 (>5\%), maka model regresi logistik yang disusun bisa digunakan untuk memprediksi nilai observasi dengan kepercayaan 95\%.

Akurasi klasifikasi model umumnya adalah $25 \%$ atau lebih tinggi daripada proporsi data. Kegunaan analisis akurasi klasifikasi model adalah untuk membandingkan akurasi model nol (model hanya dengan konstanta tanpa variabel independen) dengan full model atau model dengan menyertakan variabel bebas. Proporsi akurasi klasifikasi model dihitung dengan menggunakan proporsi klasifikasi variabel tidak bebasnya. Akurasi proporsi data dan akurasi model dapat dilihat pada Tabel 6 . 


\section{Jurnal Ekonomi Pembangunan, 16 (1), Juni 2015, 61-74}

Tabel 6. Akurasi Proporsi Data dan Model

\begin{tabular}{|c|c|c|c|}
\hline \multicolumn{4}{|c|}{ Proporsi Data } \\
\hline & & $\mathrm{n}$ & $\begin{array}{l}\text { Marginal } \\
\text { Percentage }\end{array}$ \\
\hline \multirow[t]{2}{*}{$\begin{array}{l}\text { Konsumsi } \\
\text { energi } \\
\text { listrik }\end{array}$} & $\begin{array}{l}\leq 100 \\
\text { Kwh per } \\
\text { bulan }\end{array}$ & 64 & $45,50 \%$ \\
\hline & $\begin{array}{l}>100 \\
\text { Kwh per } \\
\text { bulan }\end{array}$ & 77 & $54,50 \%$ \\
\hline \multicolumn{4}{|c|}{ Akurasi Model } \\
\hline \multirow[t]{2}{*}{ Observed } & \multicolumn{3}{|c|}{ Predicted } \\
\hline & $\begin{array}{l}\leq 100 \\
\text { Kwh }\end{array}$ & $\begin{array}{l}>100 \\
\text { Kwh }\end{array}$ & Percent \\
\hline$\leq 100 \mathrm{Kwh}$ & 42 & 22 & 65,60 \\
\hline$>100 \mathrm{Kwh}$ & 15 & 62 & 80,50 \\
\hline $\begin{array}{l}\text { Overall } \\
\text { Percentage }\end{array}$ & & & 73,80 \\
\hline
\end{tabular}

Untuk model proporsi data adalah $0,4550^{2}$ $+0,5450^{2}=0.50405(50,405 \%)$. Akurasi model dengan regresi logistik (full model) adalah
$73,80 \%$ dan lebih besar dari akurasi proporsi data. Oleh karena itu 'full model' konsumsi energi listrik rumah tangga sederhana lebih baik daripada model nolnya. Perbandingan akurasi model memperlihatkan bahwa penambahan variabel bebas di dalam kedua model yang disusun memberikan hasil yang lebih akurat dibandingkan model tanpa variabel independen sehingga dapat dijadikan prediksi dalam konsumsi energi listrik rumah tangga sederhana di Kota Medan di masa yang akan datang. Berdasarkan kriteria uji-uji tersebut di atas dapat disimpulkan bahwa secara umum model sudah layak untuk diinterpretasikan.

\subsubsection{Kalibrasi Model}

Kalibrasi adalah penentuan nilai parameter (konstanta dan koefisien) dari suatu model. Kalibrasi dan interpretasi model dapat dilihat pada Tabel 7 yaitu menganalisis variabel bebas yang mampu memberikan nilai ekspektasi yang signifikan.

Hasil estimasi parameter model dapat dilihat pada tabel 7. Pada tabel 7 dapat juga dilakukan analisis multikolinieritas atau adanya korelasi yang erat di antara masing-masing variabel bebas. Nilai standard error (S.E) setiap

Tabel 7. Variabel-variabel dalam Model

\begin{tabular}{lcccccc}
\hline \multicolumn{1}{c}{ Variabel } & B & S.E. & Wald & df & Sig. & Exp(B) \\
\hline PEND1(1) & 1.128 & 1.073 & 1.106 & 1 &, 293 & 3.090 \\
PEND2(1) &, 429 & 1.048 &, 167 & 1 &, 683 & 1.535 \\
WTP(1) & -1.548 &, 705 & 4.823 & 1 &, 028 &, 213 \\
INDAL(1) &,- 292 &, 432 &, 459 & 1 &, 498 &, 746 \\
LOKASI(1) &,- 827 &, 416 & 3.961 & 1 &, 047 &, 437 \\
DAYA(1) & -.458 &, 449 & 1.040 & 1 &, 308 &, 632 \\
KUAL(1) & 2.146 &, 564 & 14.476 & 1 &, 000 & 8.548 \\
TARIF(1) &,- 502 &, 443 & 1.282 & 1 &, 258 &, 605 \\
Constant &,- 263 & 1.446 &, 033 & 1 &, 856 &, 769 \\
\hline
\end{tabular}

Keterangan :

PEND1 (1): Pendapatan keluarga antara Rp 2 juta - Rp 4 juta per bulan, PEND2 (1): Pendapatan keluarga lebih dari Rp 4 juta per bulan, WTP(1): Harga atau Willingness To Pay keluarga untuk membayar biaya listrik dibawah Rp 100 ribu perbulan, INDAL (1): Indeks Alat Listrik keluarga dibawah 20, LOKASI (1) : Lokasi tempat tinggal keluarga di pinggir kota, DAYA (1): Daya energi listrik untuk rumah tangga tidak cukup, KUAL (1): Tanggapan terhadap kualitas energi listrik kurang baik,

TARIF (1) : Tanggapan terhadap harga energi listrik tidak terjangkau 


\section{Jurnal Ekonomi Pembangunan, 16 (1), Juni 2015, 61-74}

variabel bebas diketahui bahwa tidak terdapat nilai yang melebihi 2,0 sehingga dapat dikatakan tidak terdapat persoalan multikolinieritas (ketergantungan yang kuat antara satu variabel bebas yang satu dengan variabel yang lainnya) di dalam model tersebut.

Setelah dilakukan uji signifikansi parameter di atas maka model regresi logistik dapat dibentuk dengan menggunakan nilai taksiran parameter pada Tabel 7, sebagai berikut:

$$
\begin{aligned}
\operatorname{Ln}(\mathrm{p} / \mathrm{p}-1)= & -0,263+1,228 \operatorname{PEND} 1(1)+ \\
& \text { 0,429PEND2(1) - 1,548WTP(1) - } \\
& \text { 0,292INDAL(1) - 0,827LOKASI(1) - } \\
& \text { 0,458DAYA(1)+2,146KUAL(1) - } \\
& \text { 0,502TARIF(1). }
\end{aligned}
$$

Persamaan menunjukkan bahwa nilai konstan $=-0,263$. Artinya, $\ln (\mathrm{p} / \mathrm{p}-1)=-0,263$ pada saat semua variabel berharga 0 yaitu saat responsen memiliki karakteristik sebagai berikut: Pendapatan keluarga antara $\leq \mathrm{Rp} 2$ juta per bulan, Pendapatan keluarga antara $>\mathrm{Rp} 2$ juta - Rp4 juta per bulan, harga atau Willingness To Pay keluarga untuk membayar biaya listrik, indeks alat listrik keluarga, lokasi tempat tinggal keluarga, kecukupan daya listrik, tanggapan terhadap kualitas listrik, tanggapan terhadap harga listrik. Dengan demikian ln $(\mathrm{p} / \mathrm{p}-1)=\mathrm{e}^{-0,263}$ atau besarnya proporsi atau

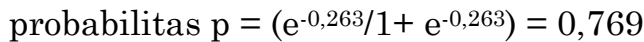

Tabel 7 memperlihatkan ada 3 variabel yang berpengaruh terhadap konsumsi energi listrik rumah tangga sederhana Kota Medan pada tingkat $5 \%$ atau dengan kepercayaan $95 \%$ yaitu Willingness to Pay (WTP), Lokasi tempat tinggal keluarga (LOKASI), dan Tanggapan terhadap kualitas listrik (KUAL).

Pengaruh dari masing-masing faktor tersebut dapat dideskripsikan dengan melihat nilai ekspektasi nilai variabel bebasnya $(\operatorname{Exp}(B)$ atau odss ratio:

1) Variabel WTP (1) memiliki odds ratio sebesar 0,213. Artinya keluarga dengan Willingness to Pay atau kemampuan membayar perKWh <
Rp100 ribu perbulan cenderung 0,213 kali lebih rendah untuk mengkonsumsi energi listrik > $100 \mathrm{KWh}$ per bulan. Atau dapat juga dinyatakan semakin tinggi kemampuan bayar (WTPKWh) keluarga, maka kecenderungan keluarga tersebut untuk mengkonsumsi energi listrik > $100 \mathrm{KWh}$ perbulan sebesar 4,694 (atau 1/0,213) kali lipat dari keluarga dengan Willingness to Pay atau kemampuan membayar perKWh $<$ Rp 100 ribu perbulan.

Berarti, semakin tinggi kemampuan bayar (WTP) keluarga maka semakin besar peluang untuk mengkonsumsi energi listrik $>100 \mathrm{KWh}$ perbulan.

2) Variabel LOKASI (1) memiliki odds ratio sebesar 0,437. Hal ini berarti keluarga yang tinggal di pinggir kota cenderung 0,437 kali lebih rendah mengkonsumsi energi listrik $>100$ KWh perbulan dibanding dengan keluarga yang tinggal di tengah kota. Atau semakin ke tengah kota tempat tinggal keluarga maka kecenderungan keluarga tersebut untuk mengkonsumsi energi listrik > $100 \mathrm{KWh}$ perbulan sebesar 2,288 (atau 1/0.437) kali lipat dari keluarga yang tinggal di pinggir kota. Berarti semakin ke tengah kota tempat tinggal keluarga maka semakin besar peluang untuk mengkonsumsi energi listrik $>100 \mathrm{KWh}$ perbulan.

3) Variabel KUAL (1) memiliki odds ratio sebesar 8,548. Artinya keluarga yang memberikan tanggapan bahwa kualitas listrik kurang baik cenderung 8,548 kali lipat mengkonsumsi energi listrik $>$ KWh perbulan dibanding dengan keluarga yang memberikan tanggapan bahwa kualitas listrik baik. Atau dengan kata lain, semakin kurang baik tanggapan terhadap kualitas listrik makan semakin tinggi peluang untuk mengkonsumsi energi listrik $>100 \mathrm{KWh}$ perbulan.

Dengan demikian model yang terbentuk adalah:

$$
\hat{\pi}=\frac{\begin{array}{c}
\exp (-0,263-1,548 W T P(1)- \\
0,827 \operatorname{LOKASI}(1)+2,146 \text { KUAL }(1)
\end{array}}{0,827 \exp (-0,263-1,548 \text { WTP }(1)-}
$$

Temuan di atas dapat untuk memprediksi responden rumah tangga yang mempunyai 


\section{Jurnal Ekonomi Pembangunan, 16 (1), Juni 2015, 61-74}

rata-rata pendapatan dan WTP yang lebih tinggi akan terus meningkatkan penggunaan energi listrik. Secara umum dapat dikatakan bahwa perubahan pendapatan akan mempengaruhi WTP yang selanjutnya akan mempengaruhi konsumsi energi listrik.

Konsumsi energi listrik berbeda secara signifikan antara rumah tangga yang tinggal di tengah kota dan yang tinggal di pinggir kota. Hasil temuan ini mengindikasikan bahwa konsumsi energi listrik lebih banyak pada rumah tangga di tengah kota dibanding dengan rumah tangga di pinggir kota. Hal ini dapat dibuktikan bahwa rumah tangga sederhana di tengah kota lebih peka terhadap faktor lingkungan seperti suhu rumah yang lebih panas, susunan rumah yang cenderung sempit sehingga banyak menggunakan alat-alat listrik seperti kipas angin, lampu, kulkas, dan lain-lain dengan durasi penggunaan listrik yang lebih lama.

Temuan yang menarik lainnya adalah semakin kurang baik tanggapan terhadap kualitas listrik maka semakin tinggi peluang untuk mengkonsumsi energi listrik. Tanggapan terhadap kualitas listrik yang kurang baik dapat mencakup: sering terjadi pemadaman dan informasinya tidak diketahui oleh rumah tangga secara luas, serta daya listrik yang sering turun naik. Kondisi ini mengkhawatirkan rumah tangga karena dapat merusak alatalat listrik yang mereka gunakan. Dengan demikian untuk mempertahankan kualitas listrik yang baik dan tidak merusak alat-alat listrik, maka rumah tangga cenderung menggunakan alat stabilizer. Penggunaan alat stabili$z e r$ tentu saja akan menaikkan konsumsi energi listrik.

\section{Simpulan}

Berdasarkan hasil estimasi regresi logistik di atas dapat ditarik kesimpulan sebagai berikut:

Di antara delapan variabel karakteristik rumah tangga yang diobservasi yang mempengaruhi konsumsi energi istrik rumah tangga sederhana TR-1/450VA, ternyata hanya tiga variabel yang berpengaruh secara signifikan yaitu WTP (willingness to pay), lokasi tempat tinggal dan tanggapan terhadap kualitas listrik.

Semakin tinggi kemampuan bayar (WTP) keluarga, maka kecenderungan keluarga tersebut untuk mengkonsumsi energi listrik $>100$ KWh perbulan sebesar 4,694 (atau 1/0,213) kali lipat dari keluarga dengan Willingness to pay atau kemampuan membayar perKWh $<$ Rp100 ribu perbulan.

Semakin ke tengah kota tempat tinggal keluarga maka kecenderungan keluarga tersebut untuk mengkonsumsi energi listrik $>100$ KWh perbulan sebesar 2,288 (atau 1/0.437) kali lipat dari keluarga yang tinggal di pinggir kota.

Semakin kurang baik tanggapan terhadap kualitas listrik makan semakin tinggi peluang untuk mengkonsumsi energi listrik $>100 \mathrm{KWh}$ perbulan.

Berdasarkan hasil penelitian ini, maka saran yang dapat disampaikan adalah sebagai berikut: 1) Penelitian ini dapat dikembangkan lagi dengan menganalisis kelompok konsumen energi listrik lainnya, seperti kelompok rumah tangga menengah dan mewah, kelompok bisnis, dan industri dengan cakupan wilayah yang lebih luas. 2) Penelitian ini dapat dikembangkan lagi dengan menggunakan variabel independen yang lebih kompleks, 3) Peran serta pihak PT. PLN (Persero) sangat dibutuhkan agar sistem pelayanan kelistrikan dapat memberikan kepuasan terhadap masyarakat. 4) Bagi penelitian selanjutnya dianjurkan menggunakan model-model lainnya agar dapat digunakan sebagai pembanding di dalam mengestimasi faktor-faktor yang mempengaruhi konsumsi energi listrik rumah tangga.

\section{Daftar Pustaka}

Agresti, A. 2002. Categorical data analysis. New Jersey: John Wiley \& Sons, Hoboken.

Amarullah, M. 1983. The pricing of electricity in Indonesia, Dissertation, The Faculty of the Department of Economics, University of Houston, Texas, USA. (tidak dipublikasikan).

Amarullah, M. 1984. Electricity demand in Indonesia: An econometric analysis. 


\section{Jurnal Ekonomi Pembangunan, 16 (1), Juni 2015, 61-74}

Publikasi LMK, No. 01-EP-84, Jakarta: Pusat Penyelidikan Masalah Kelistrikan, PLN.

Bartels, R., and Denzil G. Fiebig. 2000. Residential end-use electricity demand: results from a designed experiment. The Energy Journal, Vol. 21., No. 2, 2000, pp. 51-81.

Garbacz, C. 1984. A National micro-data based model of residential electricity demand: New evidence on seasonal variation. Southern Economic Journal, Vol. 51, Iss. 1, July 1984, pp. 235-249.

Guertin, C., Subal C. Kumbhakar, and Ananta K. Duraiappah. 2003. Determining demand for energy services: Investigating income-driven behaviours. international institute for sustainable development, 161 Portage Avenue East, $6^{\text {th }}$ Floor Winnipeg, Manitoba, Canada, http://www.iisd. org/ pdf/2003/energy determining-demand.pdf [13 Oktober 2010].

Halvorsen, B., Bodil M. Larsen, and Runa Nesbakken. 2003. Possibility for hedging from price increases in residential energy demand. Discussion Papers No. 347, April 2003, Statistics Norway, Research Department.

http://www.ssb.no/publiskasjoner/DP/dp.3 47.pdf [14 Oktober 2010].

Halvorsen, R. 1975. Residential demand for electric energy. The Review of Economics and Statistics, Vol. 57, Issue 1, pp. 12-18.

Hosmer, D. W. dan Lemeshow, S. 2000. Applied logistic regression. New York: John Wiley and Son.

Jung, T.Y. 1993. Ordered logit model for residential electricity demand in Korea. Energy Economics, Vol.15, pp. 205-209.

Kuswara, U. D. 1997. Kajian ringkas tentang energi listrik di Indonesia: Antisipasi kebutuhan dan mismanajemen dam pengelolaan. Kelola, Gadjah Mada Univer- sity Business Review, No. 15/VI/1997, pp. $105-114$.

Larsen, B. M., and Runa Nesbakken. 2002. How to quantify household electricity end-use consumption., Discussion Papers No. 346, March 2002, Statistics Norway, Research Department, http://www.ssb.no/publiskasjoner/DP/dp. 346.pdf [14 Oktober 2011].

Maddigan, R. J., Wen S. Chern, and Colleen Gallagher Rizy. 1983. Rural residential demand for electricity. Land Economics, Vol. 59, No. 2, May 1983, pp. 150-162.

McKean, J. R., and Wendell D. Winger 1992. Simultaneous equation estimates of electricity demand for the rural south: Revenue projection when prices are administered. Journal of Forecasting, Vol. 11, pp. 225-240.

Meetamehra. 2002. Demand forecasting for electricity",

http://www.teriin.org/division/regdiv/docs/ ft13.pdf.[11September 2008].

Nam, P. K., and Tran Vo Hung Son. 2005. Household demand for improved water services in ho chi min city: a comparison of contingent valuation and choice modelling estimates. Research Report No. 2005-RR3, pp.1-23, Economy and Environment Program foe Southeast Asia (EEPSEA), Singapore, http://www. eepsea. org [9 Agustus 2010].

Rab, M. A. 2001. Household energy demand in the south asia: an approach towards discrete/ Continuos Models, Dissertation, The University of Texas at Dallas.

Reiss, P. C., Matthew W. White. 2001. Household electricity demand, Revisited. http://www. nberg.org/ [12 Mei 2009].

Resosudarmo, dan Tanujaya. 2002. Energy demand in indonesia: past and future trend. The Indonesian Quarterly, Vol. XXX/2002, No.2, pp.158- 174. 


\section{Jurnal Ekonomi Pembangunan, 16 (1), Juni 2015, 61-74}

RUPTL (Rencana Usaha Penyediaan Tenaga Listrik) Tahun 2006-2015, http://www. pln.go.id.[24-3-2008].

Silk, J. I., and Frederick L. Joutz. 1997. Short and long-run elasticities in US residential electricity demand: a co-integration approach, Energy Economics (ENG), Vol. 19, Iss. 4, Oct. 1997, pp. 493-513.

Sweeney, J. L. 2004. Properties of energy resources and energy commodities. Economics Energy, Article: 48, Volume: 4.9,
Department of Management Science and Engineering, Terman Engineering Center, 323 Stanford University, Stanford, CA 94305-4026. http://www.stanford.edu/ jsweeney/paper/energy\%20 economics.pdf. [16 September 2010].

Washington, S.P., Karlaftis, M.G., Mannering, F.1. 2003. Statistical and econometric methods for transportation data analysis. USA: Chapman \& Hall. 